\title{
CHANGING EDUCATIONAL POLICIES: IMPLICATIONS FOR ICT INTEGRATION IN SCIENCE INSTRUCTION AND PERFORMANCE OF STUDENTS IN GHANAIAN SENIOR HIGH SCHOOLS
}

\author{
Mawuadem Koku Amedeker \\ University of Education, Winneba. Ghana
}

\begin{abstract}
Every country's educational policy directs the implementation and success or otherwise of education outcomes. This study analysed some educational policies of the Ministry of Education of Ghana to determine the current state of use of Information and Communication Technologies (ICTs) in science instruction in senior high schools and its implications for students' learning outcomes. Most of the policies aimed at promoting functional learning through use of ICTs. However, the various senior high school science syllabuses are not explicit on the use of ICTs such as computer, mobile technologies, print, audio-visual, radio and TV broadcasts as some of the means of integrating ICTs in teaching and learning. It was found that local stakeholders' engagement in developing the various curricula is minimal as policy documents were developed by Non-Governmental Organisations (NGOs) with occasional involvement of few personnel from the Ministry. Despite the many policy directions and training workshops given to teachers, use of ICTs in instruction has remained at the policy stages with little or no ICTs integration into school science teaching. Also ICTs integration in science teaching at the senior high school levels has been constrained by uncoordinated and a flurry of policy implementation procedures and directions given by donor agents. Students' performance in science examinations has not yielded the expected learning outcomes. It is recommended that education should be democratised to engage local practitioners of education rather than the many donor agencies seeking to correct the shortcomings of science teaching and learning.
\end{abstract}

\section{KEYWORDS}

ICTs Integration, Educational Policy, Learning Outcomes, Science Examinations, Donor Agencies

\section{INTRODUCTION}

In integrating Information and Communication Technologies (ICTs) in science instruction teachers, students and education authorities are the major stakeholders. Teachers' knowledge of the new technologies and pedagogical strategies for integration of ICTs need to be developed, while education authorities ready themselves with appropriate text books and syllabuses for professional development workshops. The concept of use of ICTs in instruction has not functionally gained grounds in Ghana despite a number of policies that have been promulgated and implemented through professional development workshops for teachers. This paper analysed some policy documents whose main thrust was on ICTs integration into teaching and learning of, especially science at the senior high school level. Also the science curricula syllabuses were studied to determine the extent to which the use of ICTs integration in instruction has been recommended in them. The paper then closely connected the senior high school leaving certificate examination results in science to the inability of science teachers to use ICTs in instruction.

\section{EDUCATIONAL RIGHTS OF INDIVIDUALS}

The 1992 Constitution of Ghana of the Republic of Ghana (Amendment) Act, 1996 under Educational Rights, Article 25, section 1 , subsections (b) and (e) is enshrined with the rights of every child to secondary (senior high) school education. It explicitly states that "25. (1) All persons shall have the right to equal educational 
opportunities and facilities and with a view to achieving the full realisation of that right; (b) secondary education in its different forms including technical and vocational education, shall be made generally available and accessible to all by every appropriate means, and in particular, by the progressive introduction of free education; (e) the development of a system of schools with adequate facilities at all levels shall be actively pursued" (Constitution of Republic of Ghana, 1992, pp. 24 - 30). Due to the rights of individuals enshrined in the Constitution a number of education policy documents have been developed to cater for the educational needs of all persons in Ghana.

\section{EDUCATION POLICY DOCUMENTS}

There has been a number of education policy documents developed and each one was expected to be a review and improvement on the previous ones. In 1987, a World Bank funded educational reform was initiated by the military-political regime of the Provisional National Defence Council (PNDC). The reforms aimed at restructuring the educational system, revising the curriculum to ingrain skills needed for school leavers and also review education financing (Little, 2010). However the hurried manner in which the reforms were implemented made some school authorities and some social groupings feel left out and hence opposed the reforms (Little, 2010). Some stakeholders felt that the reforms should have been piloted so that implementation difficulties would be detected and rectified before a wholesale implementation country-wide. This was not to be the case.

Tuition-free basic and secondary education is enshrined in the National Education Reform Report 2007 based on the 1992 Constitution of Ghana. The Report prescribed free access to education for a large number of school-going children. The current age structure of the Ghanaian population estimates that out of the 30.3 million people about 10.2 million (36.5\%) are children below the age of 15 years (Ghana Population, 2019). In response to increased access to senior high school education the total intake of students throughout the country increased from 274,255 in 2016 to 316,980 in 2018 (WAEC, 2018). This represents an increase of 15.6 $\%$ over a three-year period. In the 2018/2019 academic year there was double intake into the senior high schools countrywide with 472,000 students, representing $31 \%$ increase in intake (Graphic, 2018). The population explosion in the SHS led to the introduction of a shift system dubbed the 'Green and Gold' tracks for two batches of students, due to an immense infrastructural deficit that resulted. The Green and Gold track students alternate, while one group is on holidays the other is in school. The increase in numbers had dire consequences for science teaching as the science laboratories could not be modernised due to lack of ICT equipment.

The 2007 Report as well recommended provision of computer laboratories, internet and network connectivity to schools, supply of laptops to teachers and students and teachers' capacity development. As part of the process of equipping secondary (senior high) schools with modern state-of-the-art teaching and learning materials a number of policies were put in place by the Ghana Government. Some of the policies that expressed government's commitment to achieving ICT in education, were: (1) The Ghana ICT for Accelerated Development (ICT4AD) Policy in 2001, (2) Information and Communications Technology in Education: A Policy Framework (2002), (3) The Education Strategic Plan (2003), (4) The Ghana e-Schools Initiative High Level Business Plan (August, 2003), (5) The ICT in Education Policy (2015) and (6) Education Strategic Plan $(2018-2030)$. Each of the documents prescribed the use of ICT in Education. The main thrust of ICT in education was anchored on three main pillars which were "(i) ICT as learning and operating tool, (ii) ICT as integrated into the teaching and learning and, (iii) ICT as a career option for students" (Ministry of Education, 2015, p. 3).

The more recent Education Strategic Plan (ESP) (2018 - 2030) comprising strategic goals based on three key guiding principles was developed with one of the principles as "improved quality of teaching and learning and science, technology, engineering and mathematics (STEM) at all levels" (MoE, 2017, p. 15). Efforts at improving learning outcomes were to include "improving the skills and motivation of teachers, providing a more relevant curriculum (supported with TLMs), developing skills such as information and communication technologies (ICT)" (MoE, 2017, p. 15). The document also noted among the main problems to address over the period (Table 3.2.1, under section SE 2.1) p. 36 as: "Poor internet connection facilities in the senior high schools, Inadequacy of computers and inadequate integration of ICT in teaching and learning at SHS". The strategies proposed to solve the problems were "SE 2.1.1: Invest in TLMs and equipment in SHS". However, efforts at equipping senior high schools with ICTs and introducing STEM teaching in science are still at their initial stages. 


\section{FUNDING OF POLICY DOCUMENTS}

The development of educational policies has been funded by a number donor organisations or development partners, as they are currently termed, who bring their experts from abroad. The ESP (2018 - 2030) document was funded by the Global Partnership for Education (GPE), and the UK Department for International Development (DFID) acted as the grant agent for the GPE grant, and the United States Agency for International Development (USAID) acted as the coordinating agency.

Since 1997 approximately US \$400 million has been loaned or granted to the Education Sector in Ghana. There was an ODA (now DFID) grant of US \$8 million equivalent for Adult Literacy and teacher education; KFW and GTZ gave US \$20 million equivalent for up-grading of 35 teacher training colleges; Switzerland supported senior secondary school science equipment supply; Saudi Fund for supporting secondary school development; GTZ fund for supporting vocational school development; and Japan International Cooperation Agency (JICA) fund for supporting science, mathematics and girls education in senior high schools.

\section{POLICY IMPLEMENTATION STRATEGIES RECOMMENDED}

The Ministry of Education has indicated that equity, access and quality were their priorities in deploying ICTs in Education. Thus, a number of workshop were organised across the length and breadth of the country to raise the capacity of stakeholders, particularly teachers. In 2001 training workshops in ICTs use in teaching and learning were organised nationwide for teachers. Other workshops to discuss policies and their implementation strategies were the 'Ghana e-Schools Initiative High Level Business Plan' organised in August, 2003, the drafting of 'The 2015 ICT Policy' document which spanned the period 2009 to 2015.

The teaching syllabuses developed for teaching the various science subjects at the senior high schools were reviewed a number of times with the latest being the 2010 versions. The aim was to incorporate the 21 st century skills expected to be acquired by science students on completion of their programmes at the senior high school level. However, the teaching syllabuses for senior high school elective science subjects such as physics, biology and chemistry are not explicit on the use of ICTs in teaching and learning. The only mention of ICT is in the Chemistry syllabus. For example, items (ix) under General Aims which states that "develop the ability to communicate ideas, plans, procedures, results and conclusions of investigations orally, in writing and/or in electronic presentations" (MoE, 2010, p. ii) and under Pre-requisite Skills items (ii) and (xii) which state that "(ii) use scientific calculators; and "(xiii) use of the internet and search engines" (MoE, 2010, p. iii). The elective physics and biology syllabuses have no mention at all of ICT incorporation into teaching and learning of science.

\section{EXPECTATIONS OF THE MINISTRY OF EDUCATION}

It was the expectation of the Ministry of Education that with the incorporation of ICTs into education, teachers and students would develop new ways of accessing and analysing information. In a re-affirmation of government's intention to ensure that ICTs made impact on teaching and learning, the then Minister of Education stated "It is the government's desire that through the deployment of ICT in Education, the culture and practice of traditional memory-based learning will be transformed to education that stimulates thinking and creativity necessary to meet the challenges of the 21 st century" (Ministry of Education, 2005, p. 9). More than a decade since this intention of the Government of Ghana was made known, the teachers in the senior high schools are bereft of the knowledge of ICT integration into teaching and learning and hence science is taught without ICT integration. A number of teachers have undergone training but the nature, depth and relevance of such training for teaching and learning of science at the senior high school level remains questionable.

The expectations of excellent academic performance in the science subjects due to the deployment of the ICTs in instruction appear far from being achieved. The pass rate results for three consecutive years in the West African Senior School Certificate Examination (WASSCE) taken by senior high school students have been displayed in Table 1. Here, the pass rates are grades A1 to C6, which would qualify students to enter universities or equivalent tertiary institutions to pursue degree programmes. 
Table 1. A three-year trend in pass rates in WASSCE at grades A1 - C6

\begin{tabular}{lccc}
\hline Elective Science Subjects & 2016 & 2017 & 2018 \\
\hline Biology & $58.26 \%$ & $61.94 \%$ & $47.48 \%$ \\
Chemistry & $62.95 \%$ & $65.17 \%$ & $47.50 \%$ \\
Physics & $62.00 \%$ & $53.62 \%$ & $62.20 \%$ \\
\hline
\end{tabular}

Source: WAEC Report on trends in statistics, 2018

From Table 1, it is observed that less than half of the population of students that took the examination in biology and chemistry in 2018 met the university entry requirement. Also for the three-year period less than two-thirds of the science students who took the examination met the university entry requirements. It is, however, the expectation of the Ministry of Education that not less than $85 \%$ of senior high school students would enter universities and other tertiary institutions (MoE, 2018).

\section{KEY ACHIEVEMENTS OF SOME POLICIES}

As at 2015 there were 300 Science Resource Centres (SRCs) that had been built across the country (Dapatem, 2015). These Centres and a National Information Communication Technology (ICT) Centre set up in Accra were to serve as capacity building centres to facilitate and make the study and teaching of science in schools more ICT-oriented. The National ICT Centre was to coordinate activities with the Science Resource Centres, which were located in selected schools to serve a cluster of schools in the districts. The Japanese International Cooperation Agency (JICA) provided a grant for the completion of the SRC project whilst Phillip Harris of UK financed the construction of the buildings to house the centres. The main reasons for building the SRCs were due to lack of science equipment and the defective teaching of science at the senior high school level, as government was unable to supply science equipment to all schools (GNA, 2004).

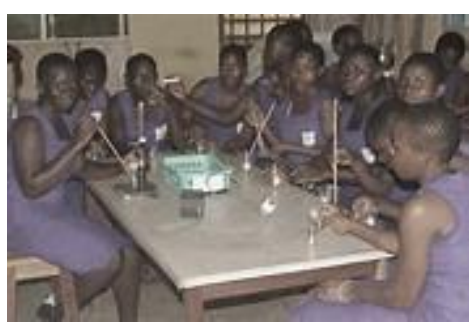

Figure 1. (a) Typical scene in SRC

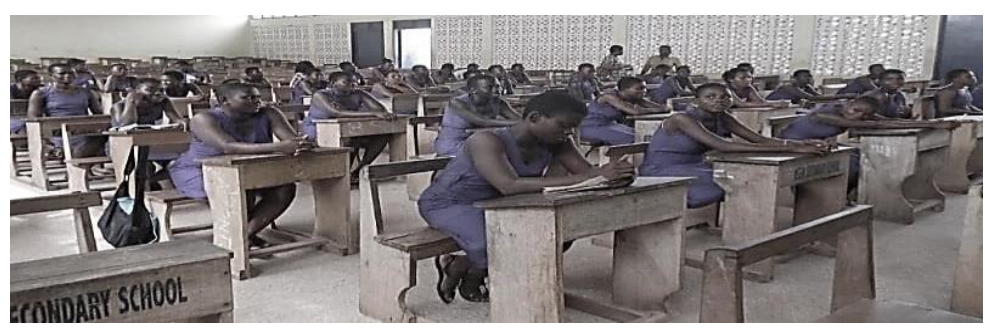

Figure 1. (b) Aftermath of the SRCs

Figure 1 (a) depicts a scene in a Science Resource Centre where senior high school students are seen at a science practical session. These students have to share the few thermometers available at the resource centre. Only the determined and aggressive students lead the practical sessions throughout while others look on. Such situations do not allow for students to have hands-on practice that the ICT policies have envisaged. As the pieces of equipment are not sufficient to go round the entire class, teachers' imagination and initiatives are overtasked.

The use of the SRCs by the satellite schools really did not last as their operations were fraught with myriads of problems. The Ministry of Education supplied buses to transport students from satellite schools to the centres but problems of fuelling of the buses could not be surmounted as schools hardly had funds to honour such obligations. Further, the distances to the centres were so long that a day's visit to a centre disrupted the school time-table for the class concerned for the day. It should be noted that the curriculum in Ghana is examination driven so teachers would not compromise completion of their subject syllabuses for a day-long laboratory practical activities. The resultant effect of the problems associated with travelling to the SRCs is depicted in Figure 1 (b) where students are taken through science practical activities while glued to their desks.

Since 2012 the Government of Ghana has made efforts at decongesting classrooms to reduce the students to teacher ratio which, stood at "46: 1 as in the 2015 - 2016 academic year" (MoE, 2017, p. 7). In 2012 the Government planned to build 200 community-day senior high schools to bring education closer to the rural communities and also to decongest the classrooms and to improve teaching and learning. The shape of the 
school blocks that were built was in the form of letter E and hence they were christened as E-Block Schools (Figure 2). As at the beginning of 2019 less than half of the 200 E-block schools had been completed with most of them not occupied due to change in government and subsequent change in policy.
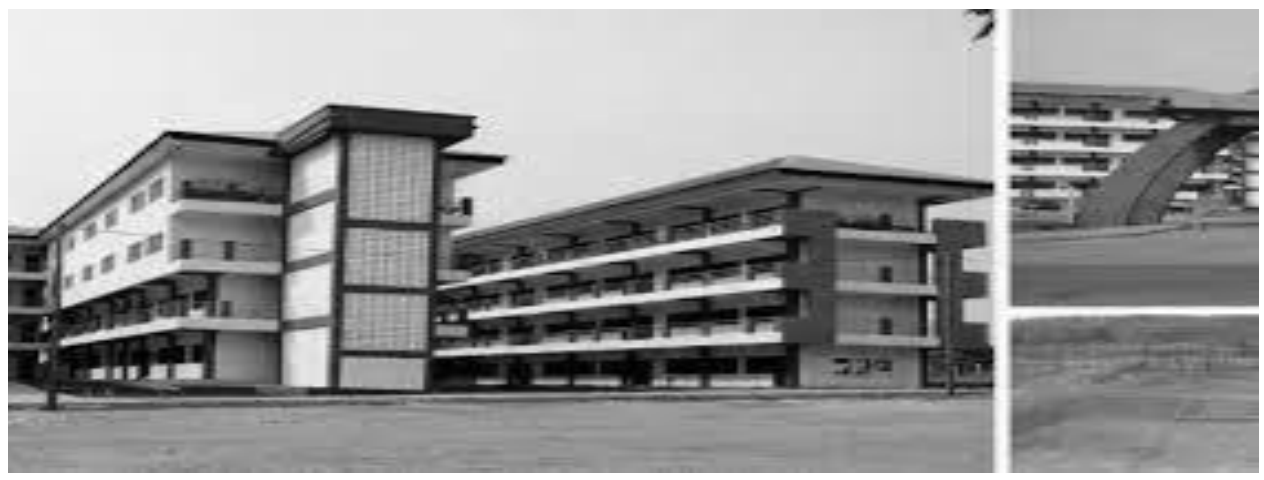

Figure 2. An E-Block senior high school building in Ghana

In 2018 the government decided on admitting the large numbers of students who qualified for entry into senior high schools from the junior high schools. This led to what has been described as 'double intake' and the students were divided into two groups - the 'Green' and 'Gold' tracks. One track was to spend four months in school while the other track remains at home for a changeover to be made at the end of the four months. In effect there was a two-semester term for each of the tracks. This step was taken to overcome the deficit in accommodations for classrooms, dining halls, dormitories and laboratories.

\section{MAJOR CHALLENGES}

The UNESCO Report (2015) which is contained in Information Paper No. 25, compared the e-readiness of Sub-Saharan African countries to integrate ICT into Education. The report indicated that evolving ICT landscape showcased a number of new technologies that the education sector policymakers widely accepted could help enhance learning and provide students with new sets of skills for them to function globally. However, the proliferation of computer hardware and software made it difficult for education authorities to decipher the appropriate and relevant ICTs to select and recommend. Similarly, it was difficult for users of ICT, such as teachers and learners, to decide on which types of ICTs to learn and use in the teaching and learning of science. There were challenges of implementation such as erratic power supply, inadequate maintenance of ICT staff, unsafe environment, infrastructural deficit and technical support (UNESCO Report, 2015). Ghana is no exception to the challenges unearthed by UNESCO.

Other challenges faced in implementation of educational policies were over-reliance on donor support to implement a number of educational projects. From 1989 to 1993 the Education Reform Programme was supported by the donor agencies: IDA, USAID, DFID, UNICEF, CIDA, EU (grants), and AGDB (loans). The multiplicity of donor agencies made the efforts of the donor agencies appear not coordinated. However, donor assistance was beneficial as it created a strategic demand for the review of educational policy documents (Mettle-Nunoo and Hilditch, 2000). It appeared, however, that the different agencies had different aims. The failure of the foreign agencies to liaise with each other and with the Ministry of Education and the Ghana Education Service (GES) led to the deployment of the ICT integration in education in only some selected schools and hence majority of schools were left out. Subsequently a number of the projects did not live beyond the implementation periods. This was due to the fact that most of the projects did not incorporate local counterpart funding aspects or if such arrangements existed they were not sustainable for a relatively poor government.

Though a number of teachers were trained to superintend the Science Resource Centres, the numbers were inadequate and even for the trained personnel there was a lack of incentives such as well-spelt out conditions of service and their future prospects. Some trained resource personnel at the SRCs found the work at the Centres more tasking than what existed at the mainstream senior high schools and hence sought transfers to the classrooms. 
A number of the school curricula, which were revised to accommodate integration of ICT only mentioned that ICT should be used to teach but the procedure for integration was not incorporated into the curricula. This left teachers stranded as to how to implement the integration. The nature of the science syllabuses gave no directions to teachers as to how to implement ICT integration in their teaching. Despite the effort by the Ministry of Education to continuously review the science syllabuses with the aim of incorporating more of the soft skills of the 21 st century not much has been achieved in that direction.

The implementation of the 'double track' system was met with a lot of opposition from civil organisations. For example, the teachers unions and concerned group like Ghana National Education Campaign Coalition (GNECC) called on government to suspend the wholesale roll-out of the double track. The reasons given were that communications concerning the roll-out were replete with inconsistencies and also the plan had not been piloted. Government's insistence on implementing the double track led to friction between government and school authorities with some of the latter being dismissed, suspend or transferred.

The lack of research on ICT integration did not augur well for ICT literacy and use among senior high school science teachers. The UNESCO Institute for Statistics (UIS) 2015 report, which monitored ICT integration in education for countries in Sub-Saharan Africa, did not have data on Ghana. This certainly is an indictment on Ghana's failed attempts at bringing into reality her numerous educational policies concerning integration of ICTs in science teaching and learning in the senior high schools.

\section{CONCLUSION}

The involvement of donor agencies in education led to the reformulation of a number of education policies in the country. For example, the new ICT policy document developed in 2015 and titled 'ICT Integration into Science Instruction' and the review of the senior high school science syllabuses were done with the aim of incorporating ICT skills acquisition. However, the apparent lack of coordination among the various teams led to early demise of a number of the education projects embarked on. In particular the SRCs quickly collapsed as supervision plans and sustenance measures were lacking. There was a lack of maintenance culture in the various laboratories and SRCs in terms of storage, repairs and refurbishment of science equipment. Staff trained in ICTs use did not remain at the SRCs due to low morale and poor conditions of service. The many workshops organised on ICTs integration in science instruction for some teachers did not yield good results as most of the schools lacked basic infrastructure such as electricity supply, internet connectivity and availability of computers. The opposition mounted against the implementation of a number of the educational policies and the lack of infrastructure to support the large number of admissions made some of the policies not workable. The integration of ICT into science instruction in the senior high schools has not made the desired impact as examination results in science have remained poor and teachers' skills in use of the ICTs have remained in doubt. Thus, policy intentions may not necessarily translate into their realisation. This study, therefore, recommends coordinated efforts by all groups attempting to charter the cause of integration of ICTs into science instruction in senior high schools in Ghana. Also government should be seen to be on top of educational policies and reduce its over-dependence on donor agencies whose activities have been seen as un-coordinated.

\section{REFERENCES}

Dapatem, D. A., 2015. Gov't sets up 100 more science resource centre. Retrieved September 11, 2019 from https://www.modernghana.com/news/286364/cape-coast-to-get-new-science-resource-centre.html

Ghana Government, 1992. Constitution of Republic of Ghana. Retrieved 9th September, 2019 from https://www.petrocom.gov.gh/wp-ontent/uploads/2018/12/constitutionofghana.pdf

Ghana News Agency (GNA), 2004._National ICT and Science Resource Centre inaugurated. Retrieved Sept 11, 2019 from https://www.modernghana.com/news/60362/national-ict-and-science-resource-centre-inaugurat.html

Ghana Population, 2019. Ghana Age Structure. Statistical Service, Accra.

GhanaWeb. Sept., 10, 2019. Why victimize Headmasters while real saboteurs of Ghana remain at post. Retrieved, Sept. 10, 2019 from https://www.ghanaweb.com/GhanaHomePage/NewsArchive/Why-victimize-Headmasters-while-realsaboteurs-of-Ghana-remain-at-post-Apaak-quizzes-779816 
Graphic., 2018. Gov't adopts double intake system for new SHS entrants. Retrieved September 13, 2019 from https://www.graphic.com.gh/news/education/gov-t-adopts-double-intake-system-for-new-shs-entrants.html

Little, A. W., 2010. Access to Basic Education in Ghana: Politics, Policies and Progress. Falmer, Sussex.

Mettle-Nunoo, R., and Hilditch, L., 2000. Donor participation in the education sector in Ghana. Action Aid -Ghana, Accra.

Ministry of Education (MoE). 2010. Teaching Syllabus for Chemistry (Senior High School 1 - 3). Curriculum Research and Development Division, Accra

Ministry of Education (MoE). 2015. ICT in Education Policy. Ministry of Education, Accra.

Ministry of Education (MoE). 2017. Education Strategic Plan (2018 - 2030). Ministry of Education, Accra.

Ministry of Education (MoE). 2018. Education Sector Review Analysis. Ministry of Education, Accra.

UNESCO Report, 2015. Information and Communication Technology (ICT) in education in Sub-Saharan Africa: A comparative analysis of basic e-readiness in schools. UNESCO, Accra.

WAEC, 2018. Report on the West African School Certificate Examination for School Candidates, 2018. WAEC, Accra. 